\title{
COUNTER-REVOLUTIONARY TRANSFORMATIONS OF CHARLES I IN BURKE, AUSTEN AND SCOTT
}

\author{
DANI NAPTON ${ }^{1}$ \\ A. D. Cousins ${ }^{2}$ \\ Macquarie University (Australia) \\ 1dani.napton@mq.edu.au \\ 2tony.cousins@mq.edu.au
}

\begin{abstract}
Few would deny Charles I's uniqueness in British history. The voluminous interpretations of Charles since his execution amply indicate the impact of his myth on subsequent generations. This essay considers mythologizings of the executed monarch by Edmund Burke, Jane Austen and Walter Scott. These three writers, albeit to different degrees and in different ways, saw his pertinence to then-current debates against revolution, that is to say, to advocacy of counter-revolution at the time of or in the shadow of the French Revolution. Specifically this essay focuses initially on Burke's Reflections on the Revolution in France which shaped the framework of much conservative thinking from 1790. Thereafter the essay considers affinities between Burke's text (and his text's divergences from) non-fiction and fiction by the politically conservative Jane Austen and Walter Scott. The focus is on two pre-eminent myths authored or authorised by the monarch himself which endured into and beyond the eighteenth and nineteenth centuries: Charles as the Royal Martyr and Charles as Christ (and, hence, as intercessor for his people).
\end{abstract}

Keywords: Counter-Revolution, Charles I, Edmund Burke, Jane Austen, Walter Scott, mythology. 


\title{
TRANSFORMACIONES CONTRARREVOLUCIONARIAS DE CARLOS I EN BURKE, AUSTEN Y SCOTT
}

\begin{abstract}
RESUMEN. Pocos negarían el carácter único de Carlos I en la historia británica. Las voluminosas interpretaciones de Carlos desde su ejecución reflejan ampliamente el impacto de su mito en las generaciones posteriores. Este artículo estudia las mitificaciones del monarca ejecutado llevadas a cabo por Edmund Burke, Jane Austen y Walter Scott. Estos tres escritores, aunque en grados distintos y de modos diferentes, vieron la pertinencia del mito respecto a los debates contra la revolución, entonces en boga; es decir, respecto a la defensa de la contrarrevolución en el tiempo de la Revolución francesa o a la sombra de ésta. En concreto, el artículo se centra inicialmente en Reflections on the Revolution in France, de Burke, que configuró el marco de gran parte del pensamiento conservador desde 1790. A partir de ahí se consideran las afinidades y divergencias entre el texto de Burke y las obras de ficción y no-ficción de los políticamente conservadores Jane Austen y Walter Scott. Se atiende especialmente a dos mitos precedentes creados y autorizados por el propio monarca que perduraron durante y más allá de los siglos dieciocho y diecinueve: Carlos como Mártir real y Carlos como Cristo (y, por consiguiente, como intercesor a favor de su pueblo).
\end{abstract}

Palabras clave: Contrarrevolución, Carlos I, Edmund Burke, Jane Austen, Walter Scott, mitología.

Received 30 April 2016

Revised version accepted 31 October 2016

But the recoiling of cruel counsels on the authors never appeared more eminently than in the death of King Charles the First whose serious and Christian deportment in it made all his former errors be entirely forgot, and raised a compassionate regard to him, that drew a lasting hatred on the actors, and was the true occasion of the great turn of the nation in the year 1660 . (Burnet 1809: 69)

Few would deny Charles I's uniqueness in British history. He is the only English sovereign to have been tried by a High Court of Justice extraordinarily promulgated by an Act of his own parliament and to have been beheaded as the result of that trial. His execution effected both the subsequent abolition of the office of King in his kingdom and his canonisation by the Church of England (as its sole saint). The voluminous interpretations of Charles since his execution amply indicate the impact of his myth on subsequent generations. In what follows, however, we consider mythologizings of the executed monarch by three writers, two of whom in particular saw his pertinence to then-current debates 
against revolution, that is to say, to advocacy of counter-revolution at the time of or in the shadow of the French Revolution. To be more specific, this essay focuses initially on Burke's Reflections on the Revolution in France which, as we know, shaped the framework of much conservative thinking from 1790, when it was first published. Thereafter the essay considers affinities between Burke's text (and his text's divergences from) non-fiction and fiction by the politically conservative Jane Austen and Walter Scott ${ }^{1}$. Central to our argument is study of how these authors evoke especially the mythos of Charles I as Royal Martyr in order to meet the perceived needs of the present. We propose that, deliberately or otherwise, Burke harmonizes his depiction of Charles with the king's image as set out in Eikon Basilike. Depicting Charles as the primary victim to violation of his country's natural political order, Burke thereby proffers a monitory reminder of where, given England's proximity to the French Revolution, Enthusiasm and a determined misreading of national history can lead. The youthful Austen, in keeping with her later literary career, briefly transforms the history of Charles' reign into a virtual romance narrative - he its protagonist and she its heroine - that indicates a deeply conservative rereading of English history. The pen of Scott fashions Charles, in effect as Royal Martyr, into an icon of imperfect because imprudent conservatism, that warns from the past against both inflexible conservatism and radical excess in the present.

1.

If I must suffer a violent death with my Saviour

it is but mortality crowned with martyrdom

(Charles I in Knachel 1966: 179)

[A] Tyrant, Traitor, Murderer, and a publick and Implacable Enemy to the commonwealth of England

(Cook 1776: 1018)

As Kevin Sharpe has recently illustrated, the myth of Charles I's transcendent kingship did not appear abruptly nor as a fully formed creation discrete from

\footnotetext{
1 Each was concerned with exploring and celebrating the merits of traditional institutions and practices that had enabled organic social progress premised on socio-political traditions guaranteeing communal order and individual freedoms. This conservatism in fact traversed the polarity of Tory and Whig politics, and prompted scrutiny of the cost of untested and radical transformations of society and politics being effected domestically and across the Channel.
} 
other aspects of mythology associated with the Stuart dynasty. The elaborate imaging of Charles as Christ-like, and indeed as another Christ, was of course not confined to him alone among the Stuarts. See, for example, Ollard (New York: 1979). James I had been transfigured by royal apologists into the Prince of Peacethis by way of placing his political pacifism beyond question, much less reproach ${ }^{2}$. Just so, imaging the monarch as Christ-like survived beyond Charles I's execution and the Interregnum in depictions where "Charles as crucified Christ gave way to Charles II as the resurrected Christ" (Knoppers 1994: 22-23). Other sympathetic representations of Charles throughout his reign imaged him as a culture hero, a triumphant Roman Emperor, King David, a philosopher-King, the mediator between God and his people, God's 'vice-regent on earth', the God-like and loving father of his loyal subjects ${ }^{3}$. By contrast, myriad contemporaneously or subsequently negative depictions sought to demythologize or demonize him. In those he becomes a tyrant, a type of Satan, the 'Man of Blood' and so on ${ }^{4}$. He was claimed to exercise "the persecuting power of the Antichrist," or "found himself juxtaposed with Richard II, and, later, Edward II, Richard III and even Nero," and cast as a "wilful King [... ] with a guilty Conscience, bloody Hands, a Heart full of broken Vowes and Protestations." See Lowenstein and Raymond in Corns (1999:

2 This title derives from Isaiah 9:6: "For unto us a child is born, unto us a son is given: and the government shall be upon his shoulder: and his name shall be called Wonderful, Counsellor, The mighty God, The everlasting Father, The Prince of Peace" (Authorized Version).

3 These positive representations of Charles were not confined to literature. Court masques such as Salmacida spolia by William D'Avenant depicted Charles as a culture hero. Representation of his gravitas, wisdom, insight and aristocratic hauteur can be seen in many of Van Dyck's paintings of Charles. The Equestrian Portrait of Charles I, for example, figures Charles as a heroic philosopher-king (via allusions to Plato's Phaedrus), carrying a baton of command while wearing the Sovereign of the Order of the Garter. Of course, any image of the king on horseback was a specific evocation of the Roman tradition of emperors represented astride a horse. Charles as the counterpart to a triumphant Roman Emperor (such as Marcus Aurelius) is evidenced in many Van Dyke paintings, including Charles I with M. de St Antoine. In his own works, Charles creates his image as a mediator between God and his people, as God's vice-regent on earth, and as the figurehead of justice. (See Sharpe 2000: especially at 183). Eikon Basilike, unsurprisingly, contains the most concentrated collection of positive images of Charles. See, for example, Knachel (1966: 75, 93-94, 120 and 133) for representations of Charles as King David. Also woven throughout Eikon Basilike is Charles, the God-like and loving father of his loyal subjects.

4 Negative depictions of Charles as a tyrant, a type of Satan, and as a 'Man of Blood' were many. John Cook, the High Prosecutor of Charles' trial, made frequent reference to Charles being "an absolute Tyrant" - see Cook (1649: 39). As we know, John Milton's Eikonklastes and Lucy Hutchinson's Memoirs of the Life of Colonel Hutchinson offer scathing comparisons between Charles and Satan. Representations of Charles as a Man of Blood can be found in various sermons of the time - including Christopher Love's, in which he "averred, that the King was a man of blood, and that it was a vain thing to hope for the blessing of God upon any peace to be made with him." See Firth (1894: I, 118). 
96 and 54-57 respectively). There is, in addition, after the regicide widespread portrayal of him as the Royal Actor. Whereas Andrew Marvell, in An Horatian Ode, used the trope both to praise and delimit Charles, John Milton deployed it in Eikonoklastes, (his counter to Eikon Basilike) to express disdain at the 'stagework' surrounding a king mindful of theatrics. Royalist supporters argued that Charles was a truly Royal Actor because, acting in accordance with God's script (and like another Jesus), he sacrificed himself on behalf of his people. Our focus here is on two pre-eminent myths that Charles instigated - or were instigated at his behest - and that endured into as well as beyond the eighteenth and nineteenth centuries. These are: Charles as the Royal Martyr; Charles as Christ (and, hence, as intercessor for his people). Each is crystallized in what was for a long time thought to be Charles' construction of his own image, in Eikon Basilike ${ }^{5}$. They frame the portrayal of Charles' personae in Burke's Reflections, Austen's History of England and Scott's "Tales of a Grandfather".

2.

First pledge our Queen this solemn night,
Then drink to England, every guest;
That man's the best Cosmopolite
Who loves his native country best.
May freedom's oak for ever live
With stronger life from day to day;
That man's the true Conservative
Who lops the mouldered branch away

Hands All Round 1-8 in Tennyson (1969: 1310)

It would not be altogether unreasonable to propose that, in its day, Burke's Reflections established the basic premises and temper of conservative political discourse within and sometimes even beyond England. His text's mythologizing the Glorious Revolution as non-violent and 'bloodless' emphatically distinguishes the latter from the regicide as well as from the more general violence of the English

\footnotetext{
While Eikon Basilike is the best known vehicle of these images of Charles, they appear widely elsewhere. Examples include: Thomas Herbert's Memoirs of the two last years of the reign of that unparallell'd prince, of ever blessed memory, King Charles I. (Herbert 1702); Richard West's A sermon preached [...] [on] the anniversary of the martyrdom of King Charles I (West 1710); William Havard's play, King Charles I, an Historical Tragedy (Harvard, 1777); and Jonathon Mayhew's A Discourse concerning Unlimited Submission and Non-Resistance to the Higher Powers: With some Reflections on the Resistance made to King Charles I. And on the Anniversary of his Death: In which the Mysterious Doctrine of that Prince's Saintship and Martyrdom is Unriddled (Mayhew 1750).
} 
Revolution, and from the Revolution occurring presently across the Channel. Burke voices concern that, unlike the recent American revolutionaries in their battle for freedom for all (or, earlier, the English in their peaceful transition to a new monarchy via the Glorious Revolution), the French were corrupting and discarding the principles by which the overthrow of their inherited governmental system had avowedly been guided. As a longstanding Whig, Burke rejected notions of the divine right of kings and supported the concept of the people's right to depose an oppressive government. Nevertheless, as his extolling the Glorious Revolution would indicate, he advocated gradual and sustained constitutional reform. Evidently disdainful of abstract schemata of government and wary of the opportunity for perversion of them in their implementations, Burke placed far greater reliance on the embedment of the people's specific, particularized liberties and rights in the constitution so to afford protection against monarchical and (or) otherwise governmental oppression. How, then, in the service of this idealized pragmatism does he represent Charles I and make use of the regicide in his Reflections?

The trial and execution of Charles I were for Burke of far more importance than was that monarch's previous life. Encompassing Burke's allusions to Charles and the English Revolution is his mythos of England's political development, namely, that it resembles the growth of a great oak. This myth premises evolution as normative with any interruption to or deviation from that (therefore) natural process being associated, most often for ill, with some extraordinary societal irruption. By contrast with his frequent references to the Glorious Revolution as an exemplum of such natural, organic development, his allusions to its chronologically close predecessor are few. Nevertheless, they are astutely deployed as supports for Burke's mythologizing of England's political growth.

Burke voiced his support of the Glorious Revolution in these terms in his 'Proposed Address to the King' on the subject of the American Revolution:

Sir, your Throne cannot stand secure upon the principles of unconditional submission and passive obedience; on powers exercised without the concurrence of the people to be governed; on Acts made in defiance of their prejudices and habits; on acquiescence procured by foreign mercenary troops, and secured by standing armies. These may possibly be the foundation of other Thrones; they must be the subversion of yours. It was not to passive principles in our ancestors, that we owe the honour of appearing before a Sovereign, who cannot feel, that he is a Prince, without knowing, that we ought to be free. The [Glorious] Revolution is a departure from the antient course of the descent of this Monarchy. The people, at that time, re-entered into their original rights; and it was not because a positive Law authorized what was then done, but because 
the freedom and safety of the Subject, the origin and cause of all Laws, required a proceeding paramount and superior to them. At that ever memorable and instructive period, the letter of the Law was superseded in favour of the substance of Liberty. To the free choice, therefore, of the people, without either King or Parliament, we owe that happy Establishment, out of which both King and Parliament were regenerated. From that great principle of Liberty have originated the Statutes, confirming and ratifying the Establishment, from which your Majesty derives your right to rule over us. Those Statutes have not given us our Liberties; our Liberties have produced them. Every hour of your Majesty's reign, your title stands upon the very same foundation, on which it was at first laid; and we do not know a better, on which it can possibly be placed. (Burke 1839: 146)

There we see distinctly that Burke builds his defence of the Glorious Revolution on this foundation: the notion that it restored their historical rights to the people. There was no violently disnuptive, unnatural and unseemly struggle for supremacy between King and Parliament; rather, the Revolution emblematizes the people's corporate resumption of their traditional and indeed innate or inherent rights. In Burke's words:

[W]e got rid of the man, and preserved the constituent parts of the state [... ] the nation kept the same ranks, the same orders, the same privileges [... ] the same rules for property [... ] the same lords. [... ] (Burke 1855: 433).

The preceding Revolution therefore was for Burke truly an aberration - a deviation that evinced a society divided against itself rather than united against an unequivocally tyrannous monarch, himself aberrant. Just as Burke's political philosophy could not countenance the notion of Charles I as governing through the divine right of kings, so it could not conveniently or comfortably accept the political irruption in which he became embroiled, namely, the English Revolution with its widespread violence, including that of the regicide itself, and its grafting a new form of government onto the English oak under the auspices of Cromwell.

Early in the Reflections, Burke makes two specific references to the period surrounding Charles I's regicide before making actual mention of Charles himself. Burke uses each as a means of arguing against Dr Richard Price, a moral philosopher, nonconformist preacher, radical political pamphleteer, and fervent supporter of American independence who was also an advocate for the French Revolution. It was of course Price's preaching his sermon, A Discourse on the Love of our Country (1789), that impelled Burke to write the Reflections (1790) by way of attempting to discredit Price's political radicalism. Burke condemns Price's sermon in vigorous terms, connecting it and its author directly with the 
revolutionary violence of 1649 (n.s.) and with those who brought it about. Here, for example, he links Price with Hugh Peters and the regicide:

That sermon is in a strain which, I believe, has not been heard in this kingdom, in any of the pulpits which are tolerated or encouraged in it, since the year 1648, when a predecessor of Dr. Price, the Reverend Hugh Peters, made the vault of the King's own chapel at St. James's ring with the honour and privilege of the Saints, who, with the "high praises of God in their mouths and a two-edged sword in their hands, were to execute judgment on the heathen, and punishments upon the people; to bind their kings with chains, and their nobles with fetters of iron." (Burke 2007: 61-62)

Burke explicitly links Price's sermon with that of Peters', in the Royal Chapel at Whitehall, which was preached as Charles' fate was being determined by his trial. Although Burke makes yet more derogatory mention of this same sermon later in the Reflections, it can be seen here that he condemns the regicide - as well as those who effected or sought to legitimize it - both politically and theologically. He alludes with heavy irony to the honour and privilege of the Saints'. The first nouns are made to seem incongruous in conjunction with the third because that last noun, 'Saints', is used to signify not merely religious self-delusion but Enthusiasm unleashed into anarchic political action (Peters' evocation of psalm 149 in his sermon being offered by Burke to instantiate the self-proclaimed Saints' habit of appropriating scripture and identifying themselves as the new Chosen People, the agents of Providence, the founders of a new social order). Shortly after, Burke makes further mention of the regicide, accusing the Revolutionary Society (and thus Price) of wilfully and duplicitously conflating the rebellion against Charles I, the Glorious Revolution and the French Revolution.

It is after these condemnatory references to Price and others unwilling to distinguish between or among the revolutions of 1649, 1688 and 1789 that Burke presents his only two direct references to Charles I in the Reflections. Having made clear his view on the regicide, he first refers to the monarch himself in the context of several other monarchs, each associated with various documents designed specifically to protect the liberties of the English populace. King John and the signing of the Magna Carta (1215) open the passage (attribution of foundational importance, not mere chronology, being the issue here), followed by Henry I and the introduction of the Charter of Liberties (1100) ensuring the rights of the nobility, church officials, and private individuals. Burke then attributes to Charles I, in conjunction with parliament, "the famous law of the 3rd of Charles I. called the Petition of Right" (1628 - see Burke 2007: 82). He climactically ends this list of monarchs who - whether personally willing or otherwise (and that is 
exactly Burke's point) - introduced decrees and statutes confirming subjects in their rights, with reference to William and Mary and the Declaration of Right that they signed upon ascending the English throne. Burke's tactic is of course to identify William and Mary, via Charles I and others, within a royal tradition of restoring and guaranteeing "the rights of Englishmen, [... ] as a patrimony derived from their forefathers". They are not just to be perceived as rulers who acquiesced in affirming 'abstract principles as "the rights of men"' (Burke 2007: ibid). Burke's symbolic deployment of Charles I implies denial that the English Revolution was a means of reinstating 'the rights of Englishmen': that had already been effected by their monarch himself and their parliament acting together.

Burke's second reference to Charles I in the Reflections occurs when he rejects notions of 'enlightenment' as justifying the anarchy resultant upon the French Revolution. As he acidly writes:

I have to remark, that Dr. Price seems rather to over-value the great acquisitions of light which he has obtained and diffused in this age. The last century appears to me to have been quite as much enlightened. It had, though in a different place, a triumph as memorable as that of Dr. Price; and some of the great preachers of that period partook of it as eagerly as he has done in the triumph of France. On the trial of the Rev. Hugh Peters for high treason, it was deposed, that when King Charles was brought to London for his trial, the Apostle of Liberty in that day conducted the triumph. "I saw," says the witness, "his majesty in the coach with six horses, and Peters riding before the king, triumphing." Dr. Price, when he talks as if he had made a discovery, only follows a precedent; for, after the commencement of the king's trial, this precursor, the same Dr. Peters, concluding a long prayer at the Royal Chapel at Whitehall, (he had very triumphantly chosen his place), said, "I have prayed and preached these twenty years; and now I may say with old Simeon, Lord, now lettest thou thy servant depart in peace, for mine eyes have seen thy salvation." Peters had not the fruits of his prayer; for he neither departed so soon as he wished, nor in peace. He became (what I heartily hope none of his followers may be in this country) himself a sacrifice to the triumph which he led as Pontiff. (Burke 2007: 116)

Throughout his elaborate parallel between Price and Peters, Burke's tactic is not ultimately to suggest that Price iterates Peters as populist demagogue, Enthusiast, and perpetrator of high treason. Nor even is it to indicate that, just as Peters was betrayed by self-delusion amidst his fantasy of 'triumph', so too Price may well be - indeed, of course, will be. Burke's further aim seems rather to be the suggestion of this. Peters believed himself to be in the vanguard of a new age, a millennial renewing of his world. Yet, although seeing himself as thus at the forefront of spiritual enlightenment, another "Simeon" heralding advent of the Kingdom, he 
was in fact a mere fanatic at the forefront of regression: of a short-lived aberration from the traditional (and, for Burke, the natural) development of his society. To this end, Burke's ironic comparatio plays Peters against Charles I, by juxtaposing reference to the King and his trial with reference to Peters as "the Apostle of Liberty". Peters believed himself to have been a prophet of and then witness to what could be called a Messianic moment, to what he and Cromwell and their fellows thought the threshold of the glorious Last Days. But he was instead, Burke intimates sardonically, a contributor to the death of the Royal Martyr. He was, in other words, not serving true religion (as he wretchedly imagined) but its opposite, not society's renewal but its undoing, not enlightenment but obscurantism.

At once confirming and concluding that implicit argument, Burke continues:

I find a preacher of the gospel [Price] prophaning the beautiful and prophetic ejaculation, commonly called "nunc dimittis," made on the first presentation of our Saviour in the Temple, and applying it, with an inhuman and unnatural rapture, to the most horrid, atrocious, and afflicting spectacle, that perhaps ever was exhibited to the pity and indignation of mankind. This "leading in triumph," a thing in its best form unmanly and irreligious, which fills our Preacher with such unhallowed transports, must shock, I believe, the moral taste of every well-born mind. Several English were the stupefied and indignant spectators of that triumph. (Burke 2007: 117)

What Peters was, Burke emphasizes, Price has become - for the latter recreates his predecessor's blind application of scriptural typology. But whereas Peters unwittingly cast himself as an anti-Simeon, in celebrating persecution of the Royal Martyr, Price has unwittingly transformed himself into a parodic Simeon who rejoices (with a kind of sexual ecstasy) in 'the most horrid, atrocious, and afflicting spectacle, that perhaps ever was exhibited to the pity and indignation of mankind'. Burke interestingly, not to say revealingly, makes the French Revolution surpass at once the regicide and the Crucifixion. Eagerly pursuing the blasphemy committed by his antagonist, he perhaps unknowingly commits the same offence.

Burke's imaging of Charles I therefore glances at the mythology of the Royal Martyr as part of a larger aim, which is to merge the horrors of the English Revolution with those of the current revolution in France. That is to say, whether by design or not Burke aligns his portrayal of Charles with that established by Eikon Basilike, in order to limn a monitory reminder of where Enthusiasm, manic self-aggrandizement, and a wilful misreading of national history can lead. It will lead, Burke asserts, not to millenarian glory but to repetition of the past's bloody failures: the foolishness of entirely avoidable political regression. 
3.

Just as Burke aligns his likeness of Charles I in his Reflections deliberately or otherwise with the lore of Stuart propaganda, so Austen seems similarly to effect that alignment in her juvenilia. Austen's concise analysis of Charles' reign in her "History of England" (1791) allows for those aspects of the chapter primarily focused on Charles himself to be quoted in full. Caricaturing the schoolroom history books popular at the time, it nonetheless expresses a political conservatism that she would explore further in Mansfield Park and, perhaps less emphatically, in other of her novels ${ }^{6}$. Austen writes:

[...] The Events of this Monarch's reign are too numerous for my pen, and indeed the recital of any Events (except what I make myself) is uninteresting to me; my principal reason for undertaking the History of England being to prove the innocence of the Queen of Scotland, which I flatter myself with having effectually done, and to abuse Elizabeth, tho' I am rather fearful of having fallen short in the latter part of my Scheme. - As therefore it is not my intention to give any particular account of the distresses into which this King was involved through the misconduct \& Cruelty of his Parliament, I shall satisfy myself with vindicating him from the Reproach of Arbitrary \& tyrannical Government with which he has often been Charged. This, I feel, is not difficult to be done, for with one argument I am certain of satisfying every sensible\& well disposed person whose opinions have been properly guided by a good Education - \& this Argument is that he was a Stuart. (Austen 2015: 165-166)

The youthful Austen, in keeping with her subsequent literary career, epitomizes the history of Charles' reign so that he becomes in effect the hero of a romance. Parliament becomes his collective antagonist, and Austen the heroine of her own narrative, for she at once denigrates Charles' then-contemporary opponent and announces that she will vindicate the king against his posthumous detractors. Her gesture towards doing so is metonymically to proffer what might be called a Stuart as distinct from a Whig view on history. Choosing to identify and defend Charles primarily via the name of his dynasty, she symbolically affirms the lore accumulated round that dynasty and in no small part generated by it (regardless of the extent to

\footnotetext{
6 The representation of Charles I in Austen's "History of England" does not of course present a developed, comprehensive or objective analysis of that monarch. Indeed Austen makes this point generally when she proclaims herself as the author of this work, being "a partial, prejudiced, \& ignorant Historian." (Austen. 2015: 151) She reinforces this in relation to that monarch, stating her intention to be "vindicating him from the Reproach of Arbitrary \& tyrannical Government with which he has often been Charged". (Austen 2015: 165-166) With these qualifications in mind, her allusion is nonetheless useful to note and worth discussion.
} 
which that lore was known to her). It is evident, for example, that she implicitly albeit tacitly foregrounds Charles as the Royal Martyr. Hers is of course merely a passing if engaged acknowledgment of Charles, and a momentary situating of him amidst a romance narrative; for a far more developed counterpart to that, we must turn to the mature writings of her contemporary, Sir Walter Scott.

4.

That Scott was politically conservative and, in fact, a staunch Tory is undisputed, although debate about the extent and nature of his conservatism (and of his related counter-revolutionism) recurs throughout critical assessments of his work. One is not surprised to discover that there is much in Burke's Reflections with which Scott would seem to have had sympathy. True, Burke was a Whig and Scott a Tory, yet both feared and rejected the extreme radicalism that they thought would disnupt the governance of society and, at the last, desolate society itself. Then, too, although they differed in their opinions on the role of the monarchy Scott being more convinced of the importance of the monarch as individual and embodiment of the body politic than was Burke - each approved of measured constitutional reform. Both distrusted theoretical schemata of politics, preferring practicable steps towards effecting positive social change. But while Scott's counter-revolutionism was influenced, like Burke's, by the events born of the French Revolution, it was also influenced by contemporary domestic political experiences and the debates associated with them. Of particular interest for Scott were political unrest in Scotland and Ireland, as well as the Peterloo massacre, in the wake of the revolution in France - all of which were associated with issues of sovereignty. Fundamental to any consideration of Scott's counter-revolutionism in connection with those phenomena - and, more broadly, with the idea of revolution itself - are Scott's representations of Charles I.

It is apparent across The Fortunes of Nigel, A Legend of Montrose, Woodstock, and Peveril of the Peak that Scott was intrigued by how three of the Stuart monarchs - James I, Charles I and Charles II - sought to establish, consolidate and legitimate their authority in what were, to say the least, unstable political environments. Fiona Robertson rightly remarks that "Scott never directly addresses himself in fiction to the downfall of Charles I"; nevertheless, his 'downfall' is considered circumspectly throughout various novels set within the years prior to his kingship and succeeding the Interregnum (1994: 230)․ In The

Fiona Robertson, Legitimate Histories: Scott, Gothic, and the Authorities of Fiction. (Oxford: Clarendon University Press, 1994): 230. Harry E. Shaw, Hugh C. Holman and Fiona Robertson all consider 
Fortunes of Nigel, for example, Scott predominantly assesses the monarchy of James I but also considers those aspects of James's reign - and of Charles' princely character - that can be inferred to have contributed to political unrest during Charles I's own rule and thence to the regicide. A Legend of Montrose is the only Waverley novel set in Charles I's reign ${ }^{8}$. Given Scott's demonstrable inclination to construct historically plausible and positive images of the Stuart monarchy, that would seem hardly a surprise; equally unsurprising, therefore, is the fact that Scott positions Charles not as the focus but rather as part of the framework to this novel. Woodstock, on the other hand, shows Charles II seeking to establish his sovereignty in a society still recovering from Charles I's execution and still teetering precariously between revolution sustained and counterrevolution. Finally, in Peveril of the Peak, Scott portrays Charles II - as individual and as king - navigating the many expectations impinging upon a post-regicide and post-Interregnum sovereignty. In that novel, both the monarch and the monarchy are under attack from disaffected parties - these being as diverse as old Royalist families and Fifth Monarchists - that are still comprehending (and recuperating from) the consequences of the events of 1649 and the years between them and the Restoration.

In his Tales of a Grandfather, however, Scott considers Charles I outside the demands imposed by romance narrative ${ }^{9}$. He provides a detailed and lengthy history of Charles' reign in the second series of that publication; but of especial interest are Chapters 41 and 45. There Scott makes reference, whether explicitly or covertly, to various images of Charles concerned with the king's natural body and his role as embodiment of the body politic. In Chapter 41, for instance, he writes:

\footnotetext{
the Civil War a central concern in The Fortunes of Nigel. Robertson suggests that the "action of The Fortunes of Nigel is overshadowed by the crisis of 1649," and notes the many references Scott makes anticipating the Civil War, thereby "foreshortening and distorting historical process." See: Harry E. Shaw's The Forms of Historical Fiction: Sir Walter Scott and His Successors (Ithaca: Cornell University Press, 1983), 174; Hugh C. Holman, 'Nigel and the Historical Imagination,' in The Classic British Novel, ed. Howard M. Harper, Jr, and Charles Edge (Athens: University of Georgia Press, 1972), 65-84, at 69; and Robertson, Legitimate Histories, 229. But see also: George A. Drake, "The Ordinary Rules of Pave': Urban Spaces in Scott's Fortunes of Nigel," Studies in the Novel 33 (2001), 416-429, at 426; Francis R. Hart, Scott's Novels: The Plotting of Historic Survival (Charlottesville: University Press of Virginia, 1966), 198.

8 Scott's original title for this was A Legend of the Wars of Montrose, but it was altered in the face of both Constable and Ballantyne's dislike to A Legend of Montrose. The Edinburgh Edition of the novel (1995) (Edinburgh: Edinburgh University Press) edited by J.H. Alexander reinstates Scott's first title.

9 Scott wrote his "Tales of a Grandfather" for his grandchild John Hugh Lockhart.
} 
It was said of [Charles I] justly, that considered as a private gentleman, there was not a more honourable, virtuous, and religious man, in his dominions. He was a kind father, an indulgent master, and even too affectionate a husband, permitting the Queen Henrietta Maria, the beautiful daughter of Henry IV of France, to influence his government in a degree beyond her sphere. Charles possessed also the personal dignity which his father totally wanted; there is no just occasion to question that so good a man as we have described him, had the intention to rule his people justly and mercifully, in place of enforcing the ancient feudal thraldom. But, on the other hand, he entertained extravagant ideas of the regal power, feelings which, being peculiarly unsuitable to the times in which he lived, occasioned his own total ruin, and, for a time, that of his posterity. [... ] [Moreover, he] disregarded the respect due to the representatives of the British people. (Scott 1836: TOAG Chapter 41, 345-6, and 374)

Scott presents Charles as his kingdom's pre-eminently Christian Gentleman, a man of gravitas. Insofar as that dignified, private gentleman had flaws, Scott implies, he did possess an imprudent charitableness that made him vulnerable to unreasonable demands or impositions - whether by his servants or even his (foreign) Queen. He was thus, we are assured, not at all inclined to tyranny. Nonetheless Scott also indicates that, as a sovereign, Charles held unreasonably to the doctrine of divine right, that dogma cherished and expounded in print by his father, James I. Hence he failed to acknowledge "the respect due to the representatives" of his subjects. What we see by way of consequence is that Scott's formal "character" of the king in the passage quoted above, although not entirely sundered from the motifs of romance narrative, seems closer to those of tragedy. What Scott articulates could in fact be called history presented as personal tragedy. This has several elements, some of which Scott highlights; others we remark because he occludes them. First, he depicts the king as a man of high estate who was at the same time, as an individual, a person of singular virtue. Then, however, he notes that this lofty figure possessed a pair of tragic flaws. The king's personal propensity to excessive love weakened his capacity to govern; his excessive belief, as a monarch, in the divine right of kings not only weakened his rule but actually "occasioned his own total ruin, and, for a time, that of his posterity". Charles becomes in effect an Aristotelian tragic hero, and the protagonist in a de casibus tragedy. Indeed, the second of his flaws brings him "total ruin" - and ruina is Latin for 'a fall'. His more extensive and less flatteringly personal flaws, the brutal implementation of his belief in divine right political theory, remain undisclosed. Scott's tragic portrayal of Charles tacitly (if not without some tactful qualifications) endorses the Stuart myth of the Royal Martyr. 
So Scott does more overtly in Chapter 45, where he describes the king's performance at his trial:

Charles behaved throughout the whole of the trying scene with the utmost dignity. He bore, without complaining, the reproaches of murderer and tyrant, which were showered on him by the riotous soldiery; and when a ruffian spit in his face, the captive monarch wiped it off with his handkerchief, and only said, "Poor creatures! for half a crown they would do the same to their father." [...] He disowned the authority of the novel and incompetent court before which he was placed; reminded those who sat as his judges, that he was their lawful king, answerable indeed to God for the use of his power, but declared by the constitution incapable of doing wrong. Even if the authority of the people were sufficient to place him before the bar, he denied that such authority had been obtained. The act of violence, he justly stated, was the deed, not of the English nation, but of a few daring men, who had violated, by military force, the freedom of the House of Commons, and altogether destroyed and abolished the House of Peers. He declared that he spoke not for himself, but for the sake of the laws and liberties of England. (Scott 1836: TOAG Chapter 45, 66-68).

Scott's theatrical trope at the start of that passage harmonizes with seventeenth-century representations of Charles' trial as tragic theatre and of the king himself as a dignified, tragic actor. One could cite, for example, Marvell's icon of the regicide within An Horatian Ode. Like Marvell, moreover, Scott draws attention to Charles' aristocratic sdegno ("Poor creatures! for half a crown they would do the same to their father"). More important than that is Scott's unmistakable affirmation of Charles in the guise of Royal Martyr. At Scott's hands, Charles' trial becomes an iteration of Christ's Passion. The king, in fact, becomes a Messianic figure, a type of the Suffering Servant prepared to sacrifice himself in the national interest. He nevertheless paradoxically remains an icon of imperfect - because wilfully impercipient - conservatism, that warns from the past against imprudent conservatism as well as radical excess in the here and now.

The emblematic significance of Charles I seems for Burke, Austen and Scott to have been essentially the same although each alludes to him for different purposes, as might well be expected. For each, the regicide is a cardinal moment in British political history and therefore each engages primarily with the enduring mythos of the Royal Martyr. That mythologizing of the monarch's trial and execution is affirmed by them with subtly various emphases. Burke, for example, chooses not to engage with inconvenient elements of Charles' rule such as his unquestioning commitment to the doctrine of divine right, the arbitrariness and instability marking his years of personal rule, and, at the last, his desperate attempt to recapture rule of his country by way of inviting the Scots to invade it. 
What matters for Burke is the polemical advantage to be gained by a focus on the violence of the English Revolution and its abortive political consequences. As Burke would have it, the regicide in particular - the death of the Royal Martyr signals the subjection of England to anarchy. Hence the regicide furnishes an exemplum for interpreting the threats to England all too clearly implicit in the French Revolution. Those who enthuse over the latter, he suggests, should consider those who chose to enthuse over the former.

Whereas Burke sets out a deliberative oration, Austen lightly and parodically proffers history as comically declarative romance fiction. Nevertheless, in doing so she looks back with assertive nostalgia to the Stuart dynasty and gestures towards Charles I (again, in the role of Royal Martyr) as an exemplar of kingly rule. Like Scott, she allows herself to be captured by Stuart mythology, which foreshadows the more reflective counter-revolutionism of her adult fiction. Scott's romances, on the other hand, although reticent about the difficulties of Charles I's monarchy, nevertheless indicate awareness of them while proposing that they could not be used to justify revolution and that the minority who brought revolution about plunged Britain into anarchy and political oppression. Such is his view, represented as tragedy, in "Tales of a Grandfather". Scott there puts forward Charles as the flawed but ultimately Christ-like sovereign who shed his blood in defence of his people's common weal. Interestingly, Scott's last remark, in the passage from Tales of a Grandfather quoted just above, connects him to some extent with Burke but, more distinctly, with the Disraeli of Sybil.

\section{REFERENCES}

Austen, J. 2015. "A History of England”. Love and Freindship: And Other Youthful Writings. Ed. C. Alexander. London: Penguin. 151-166.

Burke, E. 1839. "A Proposed Address to the King". The Works of Edmund Burke. Vol 5. Boston: Charles C. Little and James Brown.

Burke, E. 1854. The Speeches of the Right Hon. Edmund Burke, with Memoir and Historical Introductions. Ed. J. Burke. Dublin: James Duffy.

Burke, E. 1998; rpt. 2007. The Writings and Speeches of Edmund Burke, Volume VIII: The French Revolution 1790-1794. Ed. L. G. Mitchell. Oxford: Oxford University Press.

Burnet, Bishop Gilbert. 1809. History of His Own Time: From the Restoration of K. Charles II to the Conclusion of the Treaty of Peace at Utrecht, in the Reign of Queen Anne. To which is Prefixed, a Summary Recapitulation of Affairs in Church and State, from King James I. to the Restoration in the Year 1660. 
Together with the Author's Life and Some Explanatory Notes, Volume 1. London: R. H. Evans, et al.

Campbell, G. (introd.) 2010. The Holy Bible, Quatercentenary Edition: An Exact Reprint in Roman Type, Page for Page, Line for Line and Letter for Letter of the King James Version, Otherwise known as the Authorized Version Published in the Year 1611. Oxford and New York: Oxford University Press.

Cook, J. 1649. King Charles his Case. London.

Cook, J. 1776. "Journal of the Trial of King Charles I". A Complete Collection Of StateTrials And Proceedings For High-Treason And Other Crimes and Misdemeanours: Commencing With The Eleventh Year of the Reign of King Richard II. And Ending With The Sixteenth Year of the Reign of King George III: With Two Alphabetical Tables To The Whole, Volume 1. London: J. Bathurst et al.

D'Avenant, W. 2010. Salmacida spolia A masque. Presented by the King and Queenes Majesties, at White-hall, on Tuesday the 21. day of Ianuary 1639. London: Early English Drama and Theatre.

Disraeli, B. Sybil, or The Two Nations. The Badenham Edition, ed. Philip Guedalla, 12 vols. (London: Peter Davies, 1926-7).

Drake, G. A. 2001. "The Ordinary Rules of Pave': Urban Spaces in Scott's Fortunes of Nigel." In Studies in the Novel 33 no. 4 (winter): 416-429.

Firth, C. H. (ed.) 1894. The Memoirs of Edmund Ludlow. Oxford: Oxford University Press.

Hart, F. R. 1966. Scott's Novels: The Plotting of Historic Survival. Charlottesville: University Press of Virginia.

Havard, W. 1777. King Charles I, an historical tragedy; distinguishing also the variations of the theatre. London.

Herbert, Sir T. 1702. Memoirs of the two last years of the reign of that unparallell'd prince, of ever blessed memory, King Charles I. London: Printed for Robert Clavell.

Holman, H. C. 1972. "Nigel and the Historical Imagination." The Classic British Novel. Eds. H. M. Harper, Jr. and C. Edge. Athens: University of Georgia Press.

Knachel, P. A. (ed.) 1996. Eikon Basilike: The Portraiture of His Sacred Majesty in His Solitudes and Sufferings. Ithaca: Comell University Press.

Knoppers, L L. 1994. Historicizing Milton: Spectacle, Power, and Poetry in Restoration England. Athens: University of Georgia Press.

Lowenstein, D. 1999. "The King Among the Radicals." The Royal Image: Representations of Charles I. Ed. T. N. Corns. Cambridge: Cambridge University Press. 
Marvell, A. 2007. The Poems of Andrew Marvell (rev. ed). Ed. N. Smith. Harlow: Pearson Longman.

Mayhew, J. 1750. A Discourse concerning Unlimited Submission and NonResistance to the Higher Powers: With some Reflection s on the Resistance made to King Charles I. And on the Anniversary of his Death: In which the Mysterious Doctrine of that Prince's Saintship and Martyrdom is Unriddled. Boston, 1750.

Milton, J. 1957; rpt 2003. Complete Poems and Major Prose, Ed. M. Y. Hughes. Indianapolis: Hackett.

Ollard, R. 1979. The Image of the King: Charles I and II. New York: Atheneum.

Raymond, J. 1999. "Popular representations of Charles I". The Royal Image: Representations of Charles I. Ed. T. N. Corns. Cambridge: Cambridge University Press.

Robertson, F. 1994. Legitimate Histories: Scott, Gothic, and the Authorities of Fiction. Oxford: Clarendon University Press.

Scott, Sir W. 1836. "Tales of a Grandfather". The Prose Works of Sir Walter Scott Volumes XXII-XXVI. Edinburgh: Cadell.

Scott, Sir W. 1996. A Legend of the Wars of Montrose. Ed. J. H. Alexander. Edinburgh: Edinburgh University Press.

Scott, Sir W. 2004. The Fortunes of Nigel. Ed. F. Jordan. Edinburgh: Edinburgh University Press.

Scott, Sir W. 2007. Peveril of the Peak. Ed. A. Lumsden. Edinburgh: Edinburgh University Press.

Scott, Sir W. 2009. Woodstock. Ed. T. Inglis, J. H. Alexander, D. Hewitt and A. Lumsden. Edinburgh: Edinburgh University Press.

Sharpe, K. 2000. Remapping Early Modern England: The Culture of SeventeenthCentury Politics. Cambridge: Cambridge University Press.

Shaw, H. E. 1983. The Forms of Historical Fiction: Sir Walter Scott and His Successors. Ithaca: Cornell University Press.

Sutherland, J. 1973. Memoirs of the Life of Colonel Hutchinson, with the Fragment of an Autobiography of Mrs Hutchinson. Oxford: Oxford University Press.

Tennyson, A. Lord. 1969. The Poems. Ed Christopher Ricks. London: Longman's. West, R. 1710. A sermon preached before the honourable House of Commons, at St. Margarets Westminster, on Munday, Jan. 30, 1709-10, being the anniversary of the martyrdom of King Charles I. London. 